\title{
ERDŐS PÁL ÁLLAMBIZTONSÁGI DOSSZIÉJA
}

\section{PAUL ERDŐS'S FILE IN THE ARCHIVE OF THE STATE SECURITY AUTHORITY}

\author{
Pálfy Péter Pál \\ az MTA rendes tagja, kutatóprofesszor, Rényi Alfréd Matematikai Kutatóintézet \\ palfy.peter.pal@renyi.hu
}

ÖSSZEFOGLALÁS

Erdős Pál, a huszadik század kiemelkedő matematikusa 1934-től külföldön élt. Személye az ötvenes években felkeltette az Államvédelmi Hatóság figyelmét, az itthoniakkal folytatott levelezését megfigyelték, és terveket szőttek a beszervezésére.

\section{ABSTRACT}

Paul Erdős, outstanding mathematician of the twentieth century, had been living abroad from 1934. In the fifties the communist State Protection Authority checked his correspondence with his mother, friends and colleagues in Hungary, and hatched plans to exploit his international connections.

Kulcsszavak: Erdős Pál, Államvédelmi Hatóság

Keywords: Paul Erdős, Hungarian State Security Authority

Az Állambiztonsági Szolgálatok Történeti Levéltárában őrzik az Erdős Pál matematikusról összegyüjtött anyagokat tartalmazó K-1264/2 számú dossziét. Az iratok között az 1952-1957-es időszakról találhatók különféle anyagok: állambiztonsági tisztek feljegyzései, lehallgatott telefonbeszélgetések leiratai, levelek fotómásolatai, átiratai vagy fordításai; sőt számos eredeti levelet is rejt a dosszié. Bár az aktát 1965-ben lezárták, az Információs Hivatal még 1996-ban is úgy döntött, hogy az iratok államtitoknak minősítését 2015-ig fenn kell tartani, de aztán a titkosítás a 2003. évi III. törvény alapján megszünt.

Erdős Pál a huszadik század kiemelkedő matematikusa volt. A matematika számos ágában - a számelméletben, a kombinatorikában, a halmazelméletben, a valószínüségszámításban és a matematikai analízisben - ért el alapvető jelentőségü eredményeket. Szinte folyamatosan úton volt, a világ minden táján otthon érezte magát a matematikusok körében, és készen állt velük együttmüködve újabb és 
újabb szakmai problémák megoldására. Több mint 1500 tudományos dolgozatból álló gazdag életművének jelentős része más kutatókkal együttmüködve született. Társszerzőinek száma meghaladja az ötszázat.

A világi javak nem érdekelték Erdőst, saját tulajdona mindössze egypár váltás ruha volt. Különleges életmódja legendássá tette alakját. A San Franciscóban található Nüsszai Szent Gergelyröl elnevezett episzkopális templom falán a táncoló szentek sorában Mahatma Gandhi és Luther Márton között ábrázolták Erdőst (URL1). Több népszerü - bár személyiségét sajnos gyakran torzítva ábrázoló könyvet írtak róla, amelyek több nyelven is megjelentek.

Életútjának első évtizedeit itt csak tömören vázolom, Babai Lászlónak számos személyes beszélgetésen alapuló, magával ragadó stílusban megírt, igen részletes munkája (Babai, 1996) alapján. Erdős Pál 1913-ban született Budapesten. 1934-ben, mindössze huszonegy évesen doktorált a Pázmány Péter Tudományegyetemen. Annak az évnek a szeptemberétől négy esztendőn át a Manchesteri Egyetemen dolgozott. Közben évente háromszor látogatott haza, utoljára 1938 nyarán. Aztán 1938. szeptember 3-án, a közelgő veszedelmet megérezve, sietve elmenekült Magyarországról, és rövid angliai tartózkodás után az Egyesült Államokba emigrált. Először egy egyéves ösztöndíjjal a princetoni Institute for Advanced Study vendégkutatója volt, majd különböző egyetemeken kapott ideiglenes állásokat: Pennsylvania, Purdue, Stanford, Syracuse. Egy évtized elteltével tette ismét Európa földjére a lábát. Két hónapos hollandiai tartózkodás után 1948 decemberében érkezett Budapestre, ahol viszontláthatta a holokausztot túlélt édesanyját és barátait. Itthon is két hónapot töltött, majd rövid angliai látogatás után visszatért Amerikába. Aztán az 1950/51-es és 1951/52-es tanévekben ismét a szigetországban dolgozott, majd végre 1952-ben az amerikai Notre Dame Egyetemen kapott állandó állást. Ám amikor 1954-ben el akart utazni az Amszterdamban rendezett matematikai világkongresszusra - amelynek meghívott elöadója volt -, kiutazása előtt az amerikai hatóságok nem adták meg neki a visszatérésre szóló engedélyt, miután a bevándorlási hivatal tisztviselője alaposan kifaggatta, hogy olvasott-e Marxtól, Lenintől, Sztálintól, hogy mit gondol Marxról és hogy utazna-e a kommunista Magyarországra. Erdős őszinte válaszai gyanúsnak bizonyultak a mccarthyzmus légkörében. Erdős mégis elutazott a kongresszusra, a biztos állás helyett döntési szabadságát választva. Ezután évekig nem kapott vízumot az Egyesült Államokba. Az amszterdami kongresszus után Izraelben töltött több hónapot, először Jeruzsálemben a Héber Egyetemen, aztán Haifán a Technionban, ahol hamarosan állandó vendégprofesszori kinevezést kapott. (Az erről szóló értesítő levél is megtalálható a dossziéban!)

Mivel Magyarországra küldött leveleit rendszeresen ellenőrizték, tisztában voltak helyzetével. Ö maga már korábban is gondolt arra a lehetőségre, hogy hazajöjjön, amint azt barátjának, Gallai Tibornak írta: „Ha az Amerek tényleg nem hosszabbítják meg a permitet én leszek egyike az elsőknek, akik nyugatról 
menekülnek ide.” (A levél keltezése 1952. január 5. - bár az év eleji dátum miatt lehetséges, hogy az évszám téves.) Ahogy Amerikába vissza nem utazhatott, az is kétséges volt, hogy ha Magyarországra jön, megengedik-e neki, hogy utána elhagyhassa az országot. 1955 augusztusában érkezett ismét haza, miután biztosították arról, hogy szabadon utazhat. Erdős élt is ezzel a lehetőséggel, még azon az őszön Ausztriában és Belgiumban is járt.

1956. február közepén érkezett vissza Budapestre. Nem tudhatott arról, hogy az Államvédelmi Hatóságnak tervei vannak vele: „Itthon tartózkodása alatt elintézzük, hogy a magyar pártsajtóban vagy a rádióban foglalkozzanak azzal a segítséggel, melyet matematikai életünk fejlődéséhez Erdős nyújt, hogy ezzel még inkább kompromittáljuk őt az USA és Anglia kormányai felé." (L. Gy. államvédelmi százados szigorúan titkos minősítésű feljegyzése, 1956. február 18.) Azt sem sejthette, hogy ki fizette ki a szállodaszámláját: „Budapesti szállodai költségeit magunkra vállaltuk." - olvashatjuk az idézett feljegyzésben. A budapesti Béke szálló számlái (éjszakánként 33 forint, plusz a telefonköltségek) az 1956. február 18. - március 12. időszakról megtalálhatók a dossziéban.

Egy március 6-án keltezett újabb feljegyzésben további tervekről esik szó: „Alexits György akadémikus - akivel hivatalos kapcsolatban állunk - legutóbbi találkozón felvetette, hogy személyesen szeretne beszélni Piros László miniszter elvtárssal. Meg akarja kérni Piros elvtársat, hogy a Központi Vezetőség Kulturális és Tudományos Osztálya felé támogassa Erdős Pál akadémiai levelező taggá való megválasztását." Tudományos érdemei alapján Erdős Pálnak egyértelmüen a Magyar Tudományos Akadémia tagjainak sorában volt a helye, azonban külföldi kapcsolatai miatt nem csodálkozhatunk azon, hogy 1956-ban jelöléséhez az ÁVH-t felügyelő belügyminiszter egyetértését is meg kellett szerezni. Ezután az MTA május 30-i közgyülésén Erdőst meg is választották levelező tagnak. (Ö ekkor Izraelben tartózkodott, amire a május 15-én és a július 4-én lehallgatott telefonbeszélgetésekből következtethetünk. Mindkét esetben Haifáról hívta édesanyját.)

Belepillanthatunk, hogy hogyan értékelték őt az államvédelmi tisztek: „Erdős Pál zavaros, anarchisztikus kispolgári politikai nézeteket vall, de fasisztaellenessége, háborúellenessége mellénk állítja.” (L. Gy., 1956. március 6.) „Tudományos érdemei elsősorban a szám-elmélet, továbbá a halmaz-állapot [sic!] és a valószínűség-számítás terén jelentősek.” „Politikai kérdésekben teljesen tájékozatlan, naiv." (P. I., 1957. május 30.) Ez a tiszt (akkori beosztás szerint rendőrnyomozó százados) fedőnevet is választ Erdősnek: legyen ő a „Bolygó”, és elgondolkodik azon, hogy mire tudnák felhasználni Erdőst. „Javaslat: »Bolygó«-t személyi tulajdonságai miatt (rendkívül szórakozott, naiv, el van szakadva a mindennapi élettől) hírszerző munkára nem lehet felhasználni. [...] a későbbiek folyamán lehetőség nyílna a nyugaton élő magyar és más nemzetiségü tudósokról adatokat szerezni, továbbá sötétben felhasználhatnánk őt újabb tippek felkutatására, valamint aján- 
lóleveleket adhatna nyugati kollégáihoz a mi elvtársainknak.” Aki ilyen terveket dédelgetett, nem volt tisztában Erdős Pál egyenes, meg nem alkuvó jellemével!

És vajon mit gondolhatott az az államvédelmi tiszt, aki Erdős Amszterdamból 1954. október 30-án édesanyjának küldött levelében ezt olvasta: „A hatóságokkal nemcsak hogy lehet, de kell is ujjat húzni, s én csak oly országban maradok, ami ilyen. Van hol ez lehetséges, persze késznek kell lenni a következményeket viselni. Az igazán nem lényeges, hogy a jórészt tudatlan s nem túl okos hivatalnok érti-e mit miért teszek. Lényegesebb, hogy Amerikában a tudományos világ tudja, ezt próbálom terjeszteni, majd meglátjuk mennyire sikerül ez."

\section{KÖSZÖNETNYILVÁNÍTÁS}

Hálásan köszönöm Babai László és Simonovits Miklós pontosabb megfogalmazásra irányuló segítségét.

\section{IRODALOM}

Babai L. (1996): In and Out of Hungary: Paul Erdős, His Friends, and Times. In: Miklós D. - T. Sós V. - Szőnyi T. (eds.): Combinatorics, Paul Erdős is Eighty. Vol. 2. Budapest: János Bolyai Mathematical Society. 7-95.

URL1: https://www.saintgregorys.org/the-dancing-saints.html 